\title{
Physico-chemical and Microbiological Evidence of Drinking Water Quality in Ugbowo, Benin City, Nigeria
}

\author{
Ezenweani Raymond Sunday ${ }^{1}$, Ezenweani Emmanuel Chidi ${ }^{2}$ \\ ${ }^{1}$ Department of Marine Environment and Pollution Control, Faculty of Marine Environmental Management, Nigeria Maritime University, \\ Warri, Nigeria \\ ${ }^{2}$ Department of Microbiology, School of Biological Sciences, Federal University of Technology, Owerri, Nigeria
}

Email address:

raysunny65@yahoo.com (E. R. Sunday)

To cite this article:

Ezenweani Raymond Sunday, Ezenweani Emmanuel Chidi. Physico-chemical and Microbiological Evidence of Drinking Water Quality in Ugbowo, Benin City, Nigeria. International Journal of Microbiology and Biotechnology. Vol. 4, No. 1, 2019, pp. 12-18.

doi: $10.11648 /$ j.ijmb.20190401.13

Received: December 14, 2018; Accepted: April 10, 2019; Published: May 10, 2019

\begin{abstract}
Potable water is unarguably indispensable in the existence of Man. Adequate supply of safe drinking water is imperative as many dangerous diseases can be associated with unclean water used for consumption purposes. This study investigated the physico-chemical and microbiological qualities of portable water in Ugbowo, Benin City, Nigeria. A total of five different potable water sources were investigated and were selected randomly in the study place. The result showed that four of the potable water sources which include; Sources A (SA), Sources B (SB), Sources C (SC), Sources D (SD), were fit for drinking after comparing them with the WHO's, EU's, SON's standards of drinking water quality, while sample E was not found to be fit for drinking as a result of its high microbiological load after comparison with above standards. Communities should be educated and enlightened on the ill effects of consuming unclean water as vast range of water borne diseases such as cholera and typhoid can emanate from such consumption. Various NGOs and governmental agencies must deem it fit to continually investigate portable water qualities to enable urgent response when necessary.
\end{abstract}

Keywords: Portable Water, Quality, Health, Diseases, Standards

\section{Introduction}

Potable water also called drinking water in reference to its intended use is defined as water which is fit for consumption by humans and other animals [23]. The usual sources of drinking water are the streams, rivers, wells, bore holes, which are mostly untreated and associated with various health risks [2]. Water is an essential component for survival of life on earth, which contains minerals and it is important for terrestrial and aquatic lives. It is needed to replenish the fluids lost through normal physiological activities such as respiration, perspiration, urination [17].

Water plays a key role in the prevention of diseases. Drinking eight glasses of water daily can decrease the risk of colon cancer by $45 \%$ and bladder cancer by $50 \%$ as well as reducing the risk of other cancers [16]

Unsatisfactory water supplies and unwholesome sanitary conditions can result in poor human health [7]. A study in Lagos, South Western Nigeria, on wells and tap water used as drinking water sources revealed that all the wells from the locations under study were contaminated with one or more bacterial pathogens, e.g E. coli, Klebsiella pneumonia, Shigella dysenteriae, Proteus vulgaris and Salminella typhi [4]. Every year, thousands of cholera cases causing many human fatalities are said to occur in Nigeria [18]. In addition, it has been confirmed in the country that water related diarrhoea is the most prevalent disease among the population after malaria, prompting the need for safe drinking water [18]. Worldwide, roughly 1.1 billion people lack access to safe water and 1.7 billion people are said to die every year from water diarrhoea disease [9]. Consequently, the most fundamental need is provision of water that is suitable for drinking, food preparation and personal hygiene, and that poses no risk in any way to human health.

Ground water or borehole water is an important water source in both urban and rural areas of Nigeria [1]. Government and non-governmental agencies, corporate organizations and individuals are involved in sinking of boreholes to provide water 
for the families, staffs, companies and communities. Owing to the increasing demand for water, the number of boreholes in cities are correspondingly increasing annually to the extent that boreholes are becoming the principal source of drinking water in many communities. Though, the number of sachet and bottled water industries are so much increasing around the cities, according to Institute of Public Health Analyst (IPAN), 50\% of the pure water sold in the streets of Lagos may not be fit for human consumption [21]. The possibility that some situation may be applicable to other cities such as Benin City prompted the work, hence, analysis of water for physico-chemical and bacteriological quality.

\section{Materials and Methods}

\subsection{Description of Study Area}

The area for this study is Ugbowo, Benin city, Edo State, Nigeria. The topography of the place is a gentle type. It has a red laterite soil, some of which have patches of clay in them. The texture is a fine texture and soil is loamy in some part with patches of clay soil.

It is located under Longitude $\left(5^{\circ} 00 \mathrm{E}\right.$ and $\left.6^{\circ} 00 \mathrm{E}\right)$ of GreenWich meridian and Latitude $65^{\circ} 00 \mathrm{~N}$ and $6^{\circ} 00 \mathrm{~N}$. It is situated 200 miles by road, east of Lagos. The climate is within the humid tropical zone of Nigeria. The annual rainfall ranges within an average of 1500-2000 $\mathrm{mm}$ [5].

There are two temperature ranges throughout the year and it is regulated by rainfall. There is higher average temperature in the dry season and lower in the raining season. Mean annual temperature ranges from $21-30^{\circ} \mathrm{C}$. There are two major season pattern; dry and raining season [13].

It is located in the tropical rain forest zone of Nigeria and the humidity in the region supports the rain forest vegetation pattern.

The boreholes were not located in clean environment but that of sachet waters were sold in environmentally healthy places.

In this study, drinking water sample taken from different sources represented with source A (A), source B (B) source C (C), source D (D) and source E (E) were analyzed for physic-chemical properties and microbiological coliform count. SA, SB, were sachet water sold at Ugbowo, Benin City, Edo State and SC, SD were borehole waters located at Ugbowo, Benin City, Edo State while SE was a river water in the same location (Ekosodin River). $\mathrm{pH}$, electrical conductivity, turbidity, total solids, total suspended solids, total dissolved solids, chloride, nitrate, sulphate, phosphate, sodium, calcium, potassium and magnesium were analyzed using standard procedures [6].

Water sampling was done once every month for three months, and water samples for analyses were collected from each station $(\mathrm{C}, \mathrm{D}$, and $\mathrm{E})$ by using prewashed polyethylene bottles. Bottles were thoroughly washed prior to sampling to avoid contamination. For A and B, a sachet of water each was purchased from an outlet. $\mathrm{pH}$ meter, conductivity meter, turbidity meter, TDS meter (Hanna Instruments) were used for the analysis of $\mathrm{pH}$, conductivity, turbidity and TDS respectively, while other physic-chemical and microbiological coliform count was analyzed using standard procedures proposed by [6].

Microbiological analysis was done using the standard plate count method. Electronic colony counter was used to count viable organisms after incubation. All proper procedures according to ALPHA [6] were observed in the course of these analyses.

\subsection{Statistical Analysis}

Descriptive statistics such as mean, standard error and graphs were used to explain data.

\section{Results}

The physico-chemical and coliform count result obtained from analysis of the water samples are presented in Tables 1 , 2 , and 3 .

The physical conditions of the immediate environment of the water supplies were observed and revealed that such conditions could affect the quality of the potable water. The physical examinations of the borehole environments were not very clean but that of sachet waters were generally clean.

Shown in Figures 1 to 5 are results for EC, Turbidity, TDS, TSS and TS respectively. The mean value recorded for water electrical conductivity was $12.93 \pm 2.45 \mu \mathrm{S} / \mathrm{cm}$, and the maximum value was $35.00 \mu \mathrm{S} / \mathrm{cm}$, recorded in sample $\mathrm{E}$ in the month of August. The minimum value recorded was 3.00 in sample B in the month of July. The mean value recorded for water turbidity was $1.02 \pm 0.47 \mathrm{NTU}$, and the maximum value was 5.50 NTU recorded in sample $E$ in the month of July. The minimum value recorded was 0 . The mean value recorded for water total dissolved solid (TDS) was $6.554 \pm 121 \mathrm{mg} / \mathrm{l}$, and the maximum value was $19.00 \mathrm{mg} / \mathrm{l}$, recorded in sample $\mathrm{E}$ in the month of August. The minimum value recorded was $2.00 \mathrm{mg} / \mathrm{l}$ in sample $\mathrm{A}$ and $\mathrm{B}$ in the month of July. The mean value recorded for water total suspended solids (TSS) was $1.542 \pm 0.78 \mathrm{mg} / \mathrm{l}$, and the maximum value was $8.5 \mathrm{mg} / \mathrm{l}$, recorded in sample $\mathrm{E}$ in the month of August. The minimum value recorded was 0.15 $\mathrm{mg} / \mathrm{l}$ in sample A in the month of July. The mean value recorded for water total solid (TS) was $7.324 \pm 2.010 \mathrm{mg} . / 1$, and the maximum value was $27.50 \mathrm{mg} / 1$, recorded in sample $\mathrm{E}$ in the month of August. The minimum value recorded was $2.15 \mathrm{mg} / \mathrm{l}$ in sample A in the month of July.

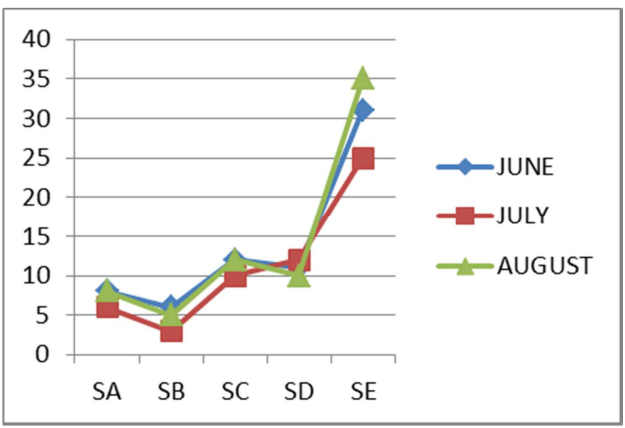

Figure 1. EC values of tested water samples during June, July and August. 


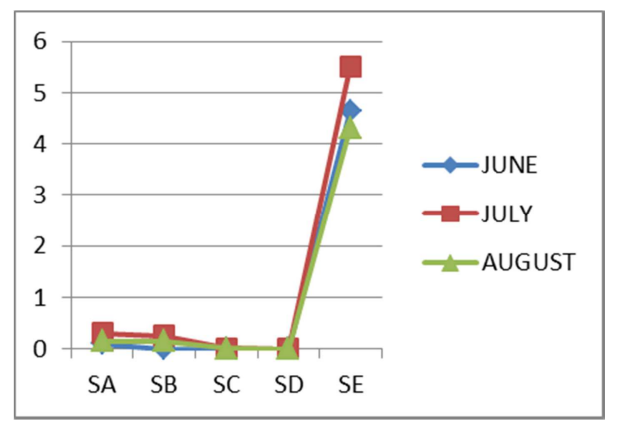

Figure 2. Turbidity values of tested water samples during June, July and August.

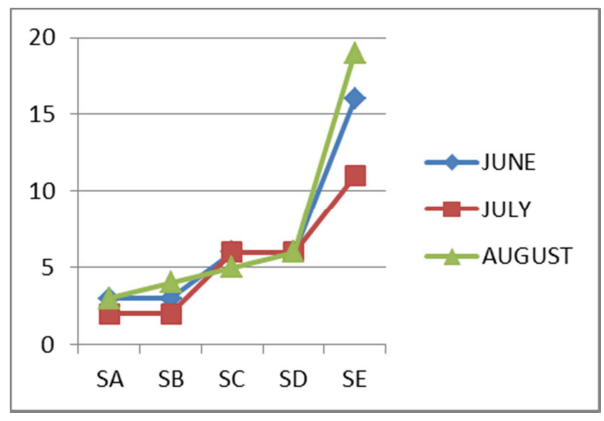

Figure 3. TDS values of tested water samples.

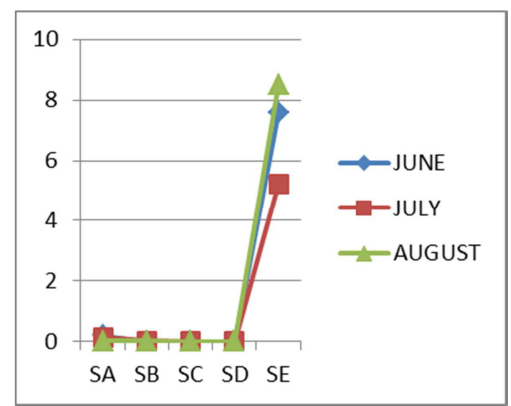

Figure 4. TSS values of tested water samples during June, July and August.

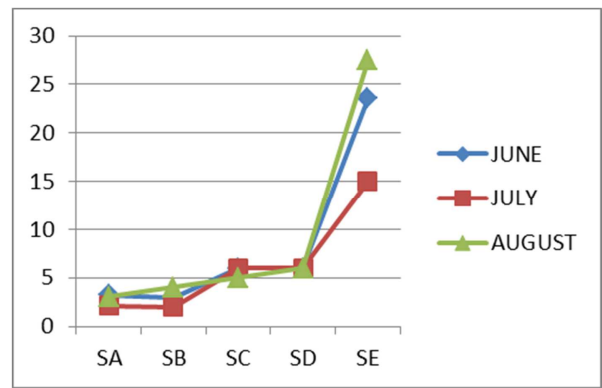

Figure 5. TS values of tested water samples during June, July and August.

Figures $6,7,8,9,10,11,12,13,14,15$, show result for $\mathrm{Cl}^{-}, \mathrm{pH}$, $\mathrm{NO}_{3}{ }^{-2}, \mathrm{SO}_{4}{ }^{-2}, \mathrm{PO}_{4}{ }^{-2}, \mathrm{Na}^{\ddagger}, \mathrm{K}^{\ddagger}, \mathrm{Ca}^{2+}, \mathrm{Mg}^{24}, \mathrm{CFU}$ count respectively. The mean value recorded for chlorine $\left(\mathrm{CL}^{-}\right)$content was $2.88 \pm 0.61 \mathrm{mg} / \mathrm{l}$, and the maximum value was $7.49 \mathrm{mg} / \mathrm{l}$, recorded in sample $\mathrm{E}$ in the month of June. The minimum value recorded was $1.2 \mathrm{mg} / \mathrm{l}$ in sample $\mathrm{C}$ and $\mathrm{D}$ in the month of August. The mean value recorded for water $\mathrm{pH}$ was $6.12 \pm 0.14$, and the maximum value was 7.00 , recorded in sample $\mathrm{D}$ in the month of June. The minimum value recorded was 5.20 in sample $\mathrm{E}$ in the month of July. The mean value recorded for water nitrate $\left(\mathrm{NO}_{3}{ }^{2-}\right)$ was $0.00233 \pm 0.0093 \mathrm{mg} / \mathrm{l}$, and the maximum value was 0.102 $\mathrm{mg} / \mathrm{l}$, recorded in sample $\mathrm{E}$ in the month of June. The minimum value recorded was 0 in sample $\mathrm{A}, \mathrm{B}, \mathrm{C}$ and $\mathrm{D}$ in the month of June, $\mathrm{C}$ and $\mathrm{D}$ in the month of July and $\mathrm{C}$ and $\mathrm{D}$ in the month of August. The mean value recorded for water sulphate $\left(\mathrm{SO}_{4}{ }^{2-}\right)$ was $0.0354 \pm 0.0170 \mathrm{mg} / \mathrm{l}$, and the maximum value was $0.230 \mathrm{mg} / \mathrm{l}$, recorded in sample $\mathrm{E}$ in the month of August. The minimum value recorded was 0 in sample $A, B, C$, and $D$ in the month of June, in B, C, D in July, in C and D in August. The mean value recorded for water phosphate $\left(\mathrm{PO}_{4}{ }^{3-}\right)$ was $0.045 \pm 0.023 \mathrm{mg} / \mathrm{l}$, and the maximum value was $0.23 \mathrm{mg} / \mathrm{l}$, recorded in sample $\mathrm{E}$ in the month of June and August. The minimum value recorded was 0 in sample A, B, C and D in the month of June, in D in the month of July and in $\mathrm{C}$ and $\mathrm{D}$ in the month of August. The mean value recorded for water sodium was $0.056 \pm 0.022 \mathrm{mg} / \mathrm{l}$, and the maximum value was $0.250 \mathrm{mg} / \mathrm{l}$, recorded in sample $\mathrm{E}$ in the month of August. The minimum value recorded was $0.003 \mathrm{mg} / \mathrm{l}$ in sample $\mathrm{C}$ in the month of July. The mean value recorded for water potassium $\left(\mathrm{K}^{\mathrm{t}}\right)$ was $0.058 \pm 0.018 \mathrm{mg} / \mathrm{l}$, and the maximum value was $0.212 \mathrm{mg} / \mathrm{l}$, recorded in sample E in the month of August. The minimum value recorded was 0.005 in sample $\mathrm{C}$ in the month of August. The mean value recorded for water calcium $\left(\mathrm{Ca}^{2}\right)$ was $0.04 \pm 0.0078 \mathrm{mg} / \mathrm{l}$, and the maximum value was $0.08 \mathrm{mg} / \mathrm{l}$, recorded in sample $\mathrm{E}$ in the month of August. The minimum value recorded was $0.006 \mathrm{mg} / \mathrm{l}$ in sample $B$ in the month of August. The mean value recorded for water magnessium $\left(\mathrm{Mg}^{2 \mathrm{f}}\right)$, was $0.047 \pm 0.013 \mathrm{mg} / \mathrm{l}$, and the maximum value was $0.02 \mathrm{mg} / \mathrm{l}$, recorded in sample $\mathrm{C}$ and $\mathrm{D}$ in the month of August. The minimum value recorded was $0.012 \mathrm{mg} / \mathrm{l}$ in sample A in the month of July. The maximum value recorded for coliform count was in sample $\mathrm{E}$ and was $3.34 \times 10^{4} \mathrm{CFU} / 100 \mathrm{ml}$, in the month of June.

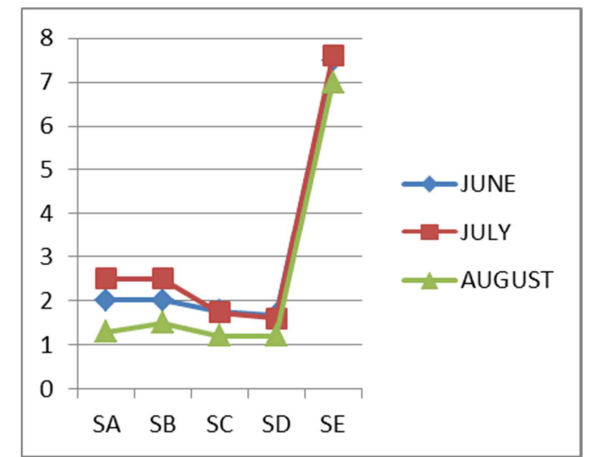

Figure 6. $\mathrm{Cl}^{-}$values of tested water samples during June, July and August.

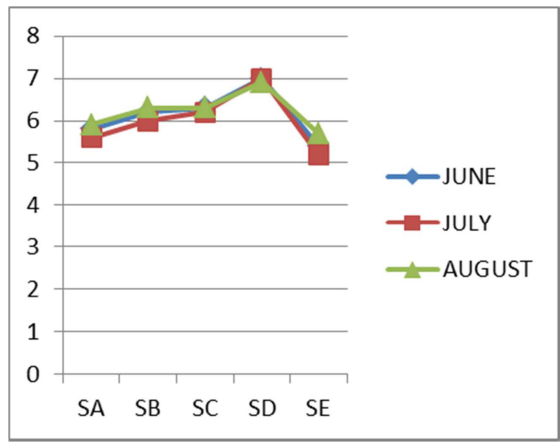

Figure 7. pH values of tested water samples during June, July and August. 


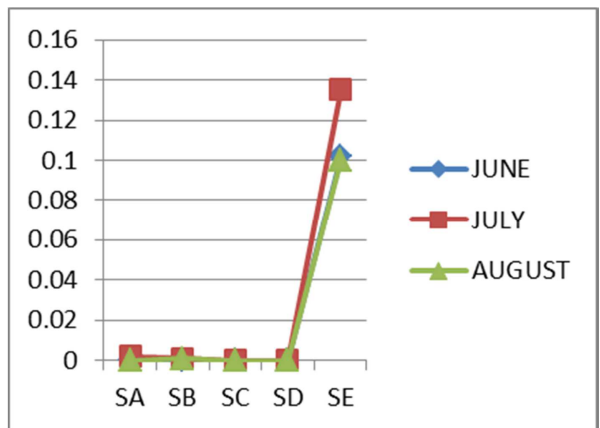

Figure 8. $\mathrm{NO}_{3}{ }^{2-}$ values of tested water samples during June, July and August.

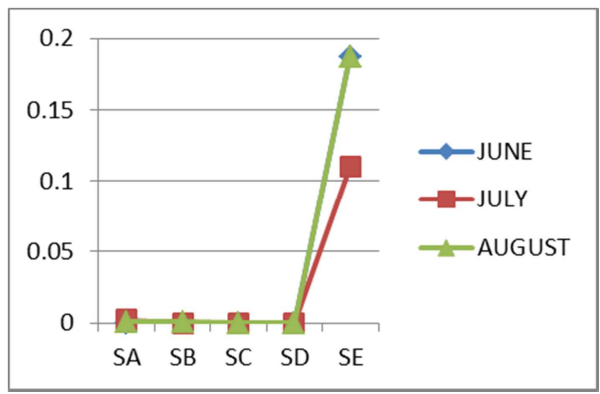

Figure 9. $\mathrm{SO}_{4}{ }^{2-}$ values of tested water samples during June, July and August.

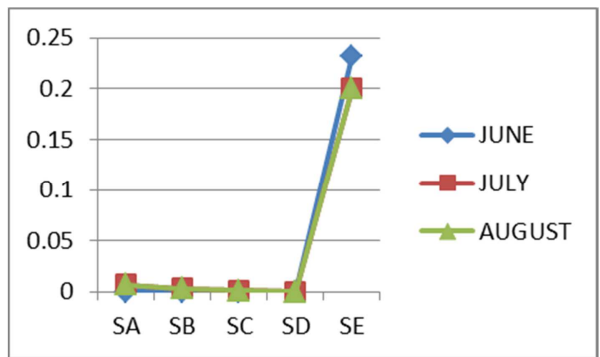

Figure 10. $\mathrm{PO}^{3^{-}}$values of tested water samples during June, July and August.

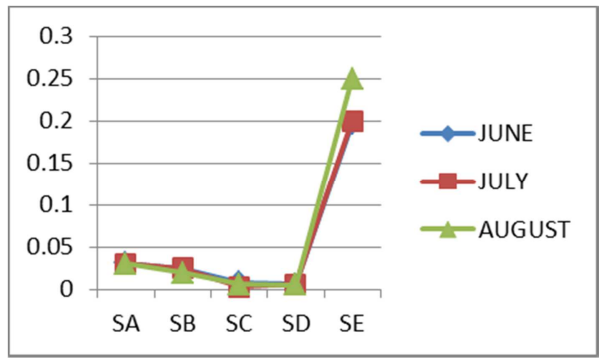

Figure 11. Nat values of tested water samples during June, July and August.

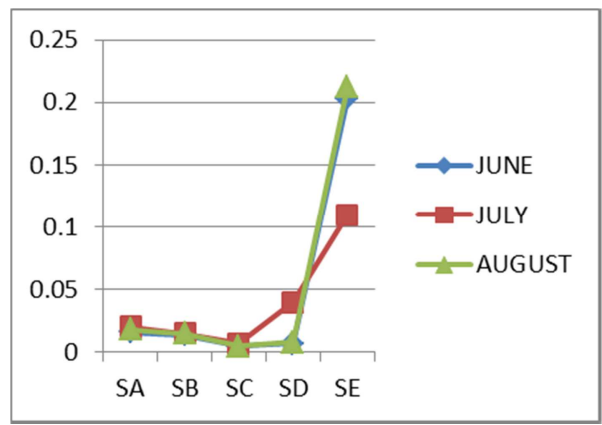

Figure 12. $K^{t}$ values of tested water samples during June, July and August.

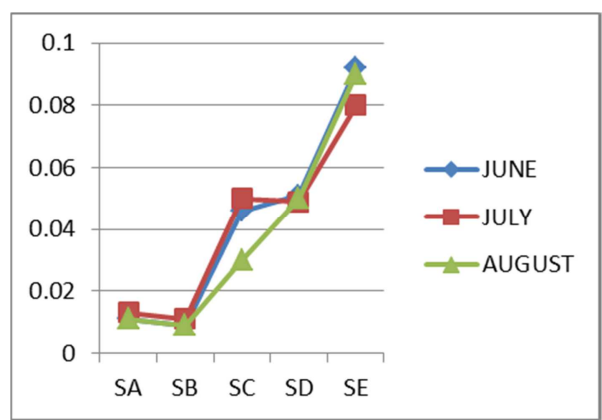

Figure 13. $\mathrm{Ca}^{2 t}$ values of tested water samples during June, July and August.

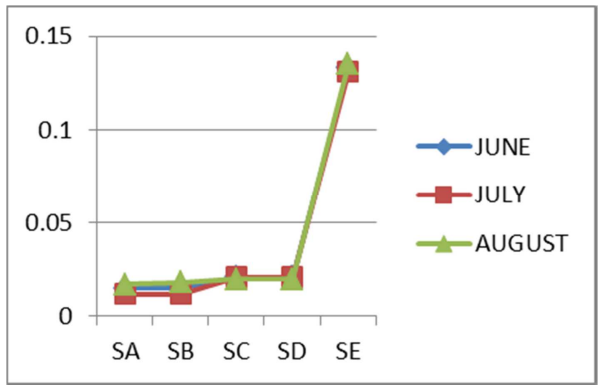

Figure 14. $\mathrm{Mg}^{2 \mathrm{2t}}$ values of tested water samples during June, July and August.

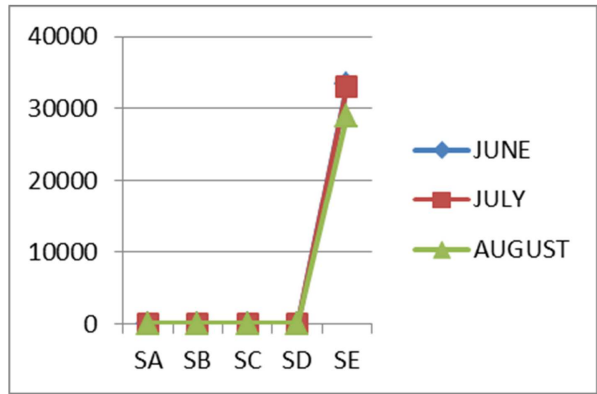

Figure 15. cfu values of tested water samples during June, July and August.

Table 1. Physico-chemical properties and coliform counts (June result).

\begin{tabular}{llllll}
\hline Parameter & Source A & Source B & Source C & Source D & Source E \\
\hline EC $(\mu \mathrm{S} / \mathrm{cm})$ & 8.00 & 6.00 & 12.00 & 11.00 & 31.00 \\
TDS $(\mathrm{mg} / \mathrm{l})$ & 3.00 & 3.00 & 6.00 & 6.00 & 16.00 \\
TSS $(\mathrm{mg} / \mathrm{l})$ & 0.20 & $\mathrm{ND}$ & $\mathrm{ND}$ & $\mathrm{ND}$ & 7.58 \\
$\mathrm{TS}(\mathrm{mg} / \mathrm{l})$ & 3.20 & 3.00 & 6.00 & 6.00 & 23.58 \\
Turbidity $(\mathrm{NTU})$ & 0.10 & $\mathrm{ND}$ & $\mathrm{ND}$ & $\mathrm{ND}$ & 4.63 \\
$\mathrm{pH}$ & 5.80 & 6.20 & 6.30 & 7.00 & 5.40 \\
$\mathrm{CL}^{-} \mathrm{mg} / \mathrm{l}$ & 2.01 & $\mathrm{ND}$ & 1.76 & 1.68 & 7.49 \\
$\mathrm{No}_{3}{ }^{-}(\mathrm{mg} / \mathrm{l})$ & $\mathrm{ND}$ & $\mathrm{ND}$ & $\mathrm{ND}$ & 0.102 \\
\hline
\end{tabular}




\begin{tabular}{llllll}
\hline Parameter & Source A & Source B & Source C & Source D & Source E \\
\hline $\mathrm{SO}_{4}{ }^{-2}(\mathrm{mg} / \mathrm{l})$ & $\mathrm{ND}$ & $\mathrm{ND}$ & $\mathrm{ND}$ & $\mathrm{ND}$ & 0.187 \\
$\mathrm{PO}_{4}{ }^{3^{-}}(\mathrm{mg} / \mathrm{l})$ & $\mathrm{ND}$ & $\mathrm{ND}$ & $\mathrm{ND}$ & $\mathrm{ND}$ & 0.232 \\
$\mathrm{Na}^{2_{+}^{+}}(\mathrm{mg} / \mathrm{l}) 1$ & 0.031 & 0.024 & 0.008 & 0.006 & 0.197 \\
$\mathrm{~K}^{\mathrm{t}}(\mathrm{mg} / \mathrm{l})$ & 0.016 & 0.014 & 0.005 & 0.007 & 0.203 \\
$\mathrm{Ca}^{+}(\mathrm{mg} / \mathrm{l})$ & 0.011 & 0.009 & 0.046 & 0.051 & 0.092 \\
$\mathrm{Mg}^{2^{+}}(\mathrm{mg} / \mathrm{l})$ & 0.015 & 0.015 & 0.021 & 0.021 & 0.133 \\
$\mathrm{Coliform}(\mathrm{CFU} / 100 \mathrm{ml})$ & $\mathrm{ND}$ & $\mathrm{ND}$ & $\mathrm{ND}$ & $\mathrm{ND}$ & $3.34 \times 10^{4}$ \\
\hline
\end{tabular}

$\mathrm{ND}=$ Not detected

Table 2. Physico-chemical properties and coliform counts (July result).

\begin{tabular}{llllll}
\hline Parameter & Source A & Source B & Source C & Source D & Source E \\
\hline $\mathrm{EC}(\mu \mathrm{S} / \mathrm{cm})$ & 6.00 & 5.00 & 10.00 & 12.00 & 25.00 \\
$\mathrm{TDS}(\mathrm{mg} / \mathrm{l})$ & 2.00 & 2.00 & 6.00 & 6.00 & 11.00 \\
$\mathrm{TSS}(\mathrm{mg} / \mathrm{l})$ & 0.15 & 0.02 & $\mathrm{ND}$ & $\mathrm{ND}$ & 6.00 \\
$\mathrm{TS}(\mathrm{g} / \mathrm{l})$ & 2.15 & 2.01 & 6.00 & 6.00 & 15.00 \\
$\mathrm{TURBIDUTY}(\mathrm{NTU})$ & 0.30 & 0.25 & $\mathrm{ND}$ & $\mathrm{ND}$ & 5.50 \\
$\mathrm{Ph}$ & 5.60 & 6.00 & 6.20 & 7.00 & 5.20 \\
$\mathrm{CL}^{-} \mathrm{mg} / \mathrm{l}$ & 2.50 & 2.50 & 1.74 & 1.60 & 7.60 \\
$\mathrm{No}_{3}{ }^{-2}(\mathrm{mg} / \mathrm{l})$ & 0.0020 & 0.0011 & $\mathrm{ND}$ & $\mathrm{ND}$ & 0.135 \\
$\mathrm{SO}_{4}{ }^{2-}(\mathrm{mg} / \mathrm{l})$ & 0.002 & $\mathrm{ND}$ & $\mathrm{ND}$ & 0.110 \\
$\mathrm{PO}_{4}{ }^{3-}(\mathrm{mg} / \mathrm{l})$ & 0.007 & 0.003 & 0.001 & $\mathrm{ND}$ & 0.200 \\
$\mathrm{Na}^{2+}(\mathrm{mg} / \mathrm{l}) 1$ & 0.030 & 0.025 & 0.003 & 0.006 & 0.200 \\
$\mathrm{~K}^{\mathrm{t}}(\mathrm{mg} / \mathrm{l})$ & 0.020 & 0.011 & 0.007 & 0.004 & 0.011 \\
$\mathrm{Ca}^{+}(\mathrm{Mg} / \mathrm{l})$ & 0.013 & 0.012 & 0.050 & 0.021 & 0.080 \\
$\mathrm{Mg}{ }^{2+}(\mathrm{mg} / \mathrm{l})$ & 0.012 & $\mathrm{ND}$ & 0.021 & $\mathrm{ND}$ & 0.131 \\
$\mathrm{Coliform}(\mathrm{CFU} / 100 \mathrm{ml})$ & $\mathrm{ND}$ & & $\mathrm{ND}$ & $3.31 \times 10^{4}$ \\
\hline
\end{tabular}

$\mathrm{ND}=$ Not detected

Table 3. Physico-chemical properties and coliform counts (August result).

\begin{tabular}{|c|c|c|c|c|c|}
\hline Parameter & Source A & Source B & Source C & Source D & Source E \\
\hline $\mathrm{EC}(\mu \mathrm{S} / \mathrm{cm})$ & 8.00 & 5.00 & 12.00 & 10.00 & 35.00 \\
\hline TDS (mg/l) & 3.00 & 4.00 & 5.00 & 6.00 & 19.00 \\
\hline TSS (mg/l) & 0.30 & 0.02 & ND & ND & 8.50 \\
\hline TS (Mm/l) & 3.03 & 4.02 & 5.00 & 6.00 & 27.50 \\
\hline TURBIDUTY (Mg/l) & 0.15 & 0.15 & 0.01 & ND & 4.30 \\
\hline $\mathrm{Ph}$ & 5.90 & 6.30 & 6.30 & 6.90 & 5.70 \\
\hline $\mathrm{CL}^{-} \mathrm{mg} / \mathrm{l}$ & 1.30 & 1.50 & 1.20 & 1.20 & 7.00 \\
\hline $\mathrm{No}_{3}{ }^{{ }^{-}}(\mathrm{mg} / \mathrm{l})$ & ND & 0.001 & ND & ND & 0.100 \\
\hline $\mathrm{SO}_{4}^{2^{-}}(\mathrm{mg} / \mathrm{l})$ & 0.001 & 0.001 & ND & ND & 0.187 \\
\hline $\mathrm{PO}_{4}{ }^{3-}(\mathrm{mg} / \mathrm{l})$ & 0.001 & 0.002 & ND & ND & 0.230 \\
\hline $\mathrm{Na}^{2+}(\mathrm{mg} / \mathrm{l}) 1$ & 0.030 & 0.020 & 0.006 & 0.005 & 0.250 \\
\hline $\mathrm{K}^{t}(\mathrm{mg} / \mathrm{l})$ & 0.018 & 0.015 & 0.005 & 0.008 & 0.213 \\
\hline $\mathrm{Ca}^{t}(\mathrm{mg} / \mathrm{l})$ & 0.011 & 0.009 & 0.030 & 0.050 & 0.090 \\
\hline $\mathrm{Mg}^{2 t}(\mathrm{mg} / \mathrm{l})$ & 0.017 & 0.018 & 0.021 & 0.020 & 0.135 \\
\hline Coliform (CFU/100ml) & 5 & 2 & $\mathrm{ND}$ & ND & $2.90 \times 10^{4}$ \\
\hline
\end{tabular}

$\mathrm{ND}=$ Not detected.

\section{Discussion}

This study has presented the physico-chemical and microbiological analysis of potable water quality of different water samples from different sources in Ugbowo, Benin City. Safeguarding drinking water supplies is a major health responsibility. The concept of safe water eludes the common Man. Consequently, the outbreak of waterborne diseases remains as a great burden on the society. The effect of drinking contaminated water results in thousands of deaths every day, mostly in children under five years in developing countries [25]. Temperature is the degree of hotness and coldness of water samples and it varies with time, months and season. While cold water is generally more palatable for drinking purpose, water with temperature above the normal human body temperature are usually not proffered, though not generally objected. There is no guideline value recommended by $\mathrm{WHO}$ with regards to temperature for 
portable water. Also, EU and SON's standards for drinking water provided no guideline for temperature.

The solid content of the water sample is grouped into two; dissolved solid (TDS) and suspended solid (TSS). The dissolved solid makes up the amount of solid that would pass through the filter paper into the flask when filtering the water sample. After heating the flask to dryness, the weight minus the weight of the flask gives the weight of the dissolved solid. For suspended solid, they will suspend on the filter paper and the weight of the suspended solid is the final weight of the filter paper minus the initial weight. The TDS and TSS determine the turbidity of the water sample. In line with the WHO'S, EU'S and SON'S standard for drinking water, TS, TDS and TSS of the water samples analyzed in this study were ok.

Turbidity ranged from 0 to 5.5 in this study. Turbidity determines the transparency and clearness of the water sample [15]. The total solids affect the task of drinking water if present at levels above the WHO's recommended $500 \mathrm{mg} / \mathrm{l}$.

Electric conductivity is a measure of the amount of ions contained in the water [19]. It quantifies the ability of water sample to conduct electric current. In this study, it ranged from 20.00 to 35.00. This is below the permitted standard for drinking water by WHO, EU, SON which are 500, 100 and 250 respectively.

$\mathrm{pH}$ measures the degree of acidity and alkalinity of the samples. High $\mathrm{pH}$ which correlates hardness of water is due to dissolved calcium and magnesium salt. Acidity, when high causes dissociation of heavy metal salts thereby producing free heavy metal ions such as lead $(\mathrm{Pb})$ and Zinc $(\mathrm{Zn})$ which can be very dangerous to the body [10]. Alkalinity can cause the reverse, the association or formation of salt of heavy metals, thereby making no free ion. In this study, the $\mathrm{pH}$ ranged from 5.2 to 7.00 . This means that the water sample were all soft water. Low $\mathrm{pH}$ indicates soft water while high $\mathrm{pH}$ indicates hard water. Hardness of water is caused by the presence of dissolved calcium and magnesium salt.

Chloride can be used to examine the salinity of water samples. In this study, it ranged from $1.2 \mathrm{mg} / 1$ to $7.40 \mathrm{mg} / \mathrm{l}$. This does not exceed the standard by WHO, EU and SON. Nitrate is a product of nitrogen and nitrogen is a very essential nutrient requirement in the body. It is used in building up of amino acid, nucleic acid, enzymes, proteins, etc. In this study, it ranged from 0 to $0.135 \mathrm{mg} / \mathrm{l}$. Nitrate accumulation can be as a result of the disintegration and accumulation of Nitrogenous substances in rivers. When deposited on the soil surface can be washed down by leaching to the water table and can then contaminate the bole hole. In line with WHO's, EU's and SON' standard for drinking water, this does not exceed the maximum standard. Reason for customers complains is majorly taste. [12] reported that nitrate concentration above the recommended value of $10 \mathrm{mg} / \mathrm{l}$ is dangerous to pregnant women and possess a serious health threat to infants in less than three to six months of age because of its ability to cause mathemoglobinaemia or blue baby syndrome in which blood loses the ability to carry oxygen. [16] reported nitrate concentrations up to $124 \mathrm{mg} / \mathrm{l}$ and nitrite up to $12 \mathrm{mg} / \mathrm{l}$ in shallow ground water near pollution source in south west Nigeria. These concentrations were unusually high [10].

Levels of sulfate above $600 \mathrm{mg} / \mathrm{l}$ act as purgative in humans [24]. Sulphate is a measure of sulphur content. Water bodies can be contaminated with sulphate from the course of washing of cars, house hold utensils with detergents which can wash into the water bodies or sink down the water table through leaching or infiltration to contamination the boreholes. In this study, sulphate ranged from 0 to $0.187 \mathrm{mg} / \mathrm{l}$. In line with WHO, EO and SON standards, sulphate did not exceed the standards.

Phosphate is a product of phosphorus. Water bodies can be contaminated from the courses of washing with phosphorus containing detergents in it. This can get to the water table through leaching, infiltration and seepage from water bodies to water table [14]. Phosphorus is a constituent of DNA or RNA. Through the infiltration of detergents down the water table, other organic and inorganic chemical constituents can get to contaminate the water table. In this study, it ranges from 0 to $0.232 \mathrm{mg} / \mathrm{l}$ and was below recommended standards.

Calcium and magnesium content give rise to hardness [10]. In this study, calcium ranges from $0.009 \mathrm{mg} / 1$ to $0.0072 \mathrm{mgl}$ with highest found in Sample $\mathrm{E}$ and magnesium ranged from $0.012 \mathrm{mg} / 1$ to $0.135 \mathrm{mg} / 1$ with highest found in sample $\mathrm{E}$. According to this study, the calcium and magnesium content of the water samples did not exceed any of the Standards. Calcium and magnesium are majorly needed minerals for the building and strengthening of the bones, teeth gum and tissues [8]. High calcium and magnesium concentration have been linked to outcomes in heart disease in communities with hard water [8]. Sodium and potassium were also found not to be above recommended standards.

Coliform count or population is an indicator for pathogenic organisms. They should not be found in drinking water but are usually present in surface water. Though it would be difficult to determine the presence of all bacteria in a sample, certain types of microorganisms can serve as indicators of pollution [20]. Chief among these are the coliform bacteria which survive better, longer and they are easier to detect that other pathogens [3]. Waste contaminants in water causes water-borne diseases such as diarrhea, typhoid, hepatitis, etc [22]. Coliform count is the count of viable microbial colony unit in water sample. From the result, sample A, B, C and D were free while the range was $2.90 \times 10^{4}$ to $3.34 \times$ $10^{4} \mathrm{CFU} / 100 \mathrm{ml}$ in sample E. In line with the WHO, EU and SON drinking water quality standards, Sample A, B, C, D were fit for drinking while Sample E was not fit for drinking as it has high microbial content. This could have resulted from water pollution as a result of several anthropogenic activities taking place at the sample site. Therefore, adequate water treatment must be ensured before usage.

\section{Conclusion}

It was evident from this study that source A, B, C and D from the different drinking water sources in Ugbowo, Benin 
City, Edo State, consumed at the time of this study met the WHO's, EU's and SON's recommended standards for drinking water, while source E did not meet these standards. Water users should be on watch and continuous investigation on drinking water should be paramount to report possible exceeding of microbiological and physico-chemical standards to appropriate authorities in order to sustain water fitness for consumption.

\section{References}

[1] Adekunle IM, Adetunji MT, Gbadebo AM and Banjoko OB (2007) Ground water contamination in basement-complex area of Ile-Ife, South Western Nigeria. A case study using the electrical-resistivity of geographical method. Hydrogeo. Journ. 1: 611-622.

[2] Agbaire PO and Obi CG (2009). Seasonal variations of some physico-chemical properties of River Ethiope water in Abraka, Nigeria J. Appl. Sci. Environ. Manage. 13 (1): 55-57.

[3] Agunwambe JC (2000) Eater Engineering Systems. $2^{\text {nd }}$ Edition. Enugu Immaculate Publication limited. PP. 33-134.

[4] Akinyemi KO, Oyetolu AOB, Salu OB, Adewale AA and Fasume AK (2006) Bacterial pathogens associated with top and well water in Lagos, Nigeria. East and Central Africa. Journ. of Surg. 1: 110-117.

[5] Akujieze, C. N. (2004). Effects of anthropogenic activities (sandquarrying and waste disposal) on urban groundwater system and aquifer vulnerability assessment in Benin City, Edo State, Nigeria. PhD Thesis, University of Benin, Benin City, Nigeria.

[6] APHA (2007) Standard methods for the examination of water and wastewater (23rd ed.). Eds. Andrew D Eaton, EW Rice and RB Baird. American Public Health Association, Washington DC.

[7] Chukwu GU (2008) Water quality assessment of boreholes in Umuahia South LGA of Abia State, Nigeria. The Pacific Journ. Sci. Techn. 2: 592-598.

[8] Chinedu SN, Nwinyi OC, Olwandanisi AY and Eze VN (2011) Assessment of water quality in common land, Ota, South West Nigeria. Agric. Bio. Journ. America 4: 577-583.

[9] Cutler D and Miler D (2005) The role of public health improvements in health advances. Twentieth contury united state demography 42: 1-22.

[10] Edema MO and Atayese AO (2002) Pure water syndrome: Bacteriological quality of sachet packed drinking water sold in Nigeria. Afr. Journ. Sci. 6: 230-237.

[11] El-Sharkawy AM, Sahota O, and Lobo DN (2015). Acute and chronic effects of hydration status on health. Nutrition Reviews, 73 (S2): 97-109.
[12] Groen J, Suchumann JB and Germaer TW (1988) The occurrence if high nitrate concentration in ground water in villages in North Western Burkina Faso. Journ. of Afr. Earth Sci 18: 237-245.

[13] Ikhile C. I. and Olorode D. O. (2012). Climate change and water balance in the Osse-Ossiomo sub-basin of S. W. Nigeria. Port Harcourt Journ. of Social Sci 3: 98-109.

[14] Kolo JB, Dibal MJ and Ndukowa II (2009) Elemental analysis of tap and borehole water in Maiduguri Seri Arid Region, Nigeria. Eu. Journ. App. Sci. 2: 20-27.

[15] Kurup R, Persaud R, Ceaser J and Reja V (2010) Microbiological and physiochemical analysis of drinking water in George Town, Tayana. Nat. and Sci. 8: 20-27.

[16] Malomo S, Okufarasin VA, Olurumio MA and Omode AA (2014) Ground water chemistry of wealthered zone aquifers of an area underlain by basement complex roacks. Journ. Afri. Earth Sci. 11: 357-371.

[17] Murray J., Taylor W. S., Zhang B., Ghosh S. S and Capaldi A. R. (2003). Oxidative damage to mitochondrial complex 1 due to peroxynitrite; Identification of reactive tyrosines by mass spectrometry. J. of Biol. Chem. 1-40.

[18] Njokwu C and Ozinlu A (2007) New standard for drinking water quality in Nigeria to ensure the safety of drinking water and protect public health. WHO. Ll www.unicet.org/Nigeriawas2165.ht.onl.

[19] Onweluzo JC and Akuabgazie LA (2010) Assessment of the quality of bottle and sachet water sold in Nsukka town. Journ. Trop. Agric. Fd. Env. and Extens. 2: 104-110.

[20] Opavaocha ET, Eroegbu OC and Obi RK (2010) Assessment of quality of drinking water sources in the Federal University of Technology, Owere. Imo State, Nigeria. Journ. App. Biosc. 32: 1964-1976.

[21] Osibanjo O, Ajayi F and Akiyanju P (2000) Public analysis reporting system as applied environmental issues. IPAN News, A publication of the Institute of Public Analysis 13: 10.

[22] Oyadeji O, Olutiola PD and Moninuala MA (2008) Microbiological quality of packaged drinking water brands marketed in Ibadan metropolis and Ile-Ife City in South Western Nigeria. Afr. Journ. Micro. Res. 1: 96-102.

[23] Tchobanoglous G, Burton FL and Stensel HD (2003) Waste water engineering (Treatment disposal reuse) In: Metcalf and Eddy inc. (ed) (41th edition). McGraw-Hill book company. Pp 83-95.

[24] Teshamulora O (2007) Water quality and business aspects of sachet-vended water in Tamale, Ghana. M.Sc. Thesis, Department of Civil and Environmental Engineering, Massachuseetes, Institute of Technology.

[25] World Health Organization (2004) Guidelines for Drinking Water qualities. Switzerland, Volume $1,3^{\text {rd }}$ edition. WHO Press Switzerland. 